\title{
Weed Management in Rice ${ }^{1}$
}

\author{
D. C. Odero and M. VanWeelden²
}

Rice is an important crop in the Everglades Agricultural Area (EAA) and surrounding region of south Florida. It is cultivated during the fallow renovation period in the sugarcane cropping system. Up to two harvests of rice can be obtained in the subtropical climate of south Florida depending on planting date and the level of weed and/or insect infestation in the first crop. Therefore, successful weed control is essential for economical rice production in Florida. Weeds reduce rice yields by competing for moisture, nutrients, and light during the growing season. Factors such as weed species composition, weed density, duration of weed-rice competition, rice cultivar, seeding density, water management, and fertility level influence the degree of rice yield loss from weed competition. The influence of rice cultivars on weed competition is often overlooked. Short-statured or dwarf cultivars, early-maturing cultivars, and erect cultivars are usually less competitive with weeds compared to tall, late-maturing, and drooping cultivars. Weed infestations can also interfere with combine operation at harvest and significantly increase harvesting and drying costs. Weed seed contamination of rice grain lowers grain quality and may lower the cash value of the crop. In addition, weeds harbor pathogens and insect pests and increase the soil weed seedbank, which becomes a source of re-infestation in subsequent crops. As with any biological system, an effective weed management program for rice must consider many factors that vary from crop to crop and year to year. The most important of these factors include planting date, climatic conditions, seedbed preparation, seed quality, stand establishment, and water management.

In Florida, rice is drill-seeded into dry seedbeds. The dominant weed species are fall panicum (Panicum dichotomiflorum), bearded sprangletop (Leptochloa fascicularis), goosegrass (Eleusine indica), yellow nutsedge (Cyperus esculentus), purple nutsedge (C. rotundus), and spreading dayflower (Commelina diffusa). Other weed species include amazon sprangletop (L. panicoides), common purslane (Portulaca oleracea), spiny amaranth (Amaranthus spinosus), alligatorweed (Alternanthera philoxeroides), rice flatsedge (Cyperus iria), primrose willow (Ludwigia sp.), and redstem (Ammania sp.). Recently, barnyardgrass (Echinochloa crus-galli) has been reported in some rice fields in Florida. It is likely that barnyardgrass was introduced in contaminated seed because it is a species not commonly associated with sugarcane, the main crop in the region. Weed infestations in rice fields occur as mixed weed populations with no monoculture of single species. Correct weed identification at the seedling stage is therefore an important step in determining management strategies.

1. This document is SS-AGR-10, one of a series of the Agronomy Department, UF/IFAS Extension. Original publication date January 2000. Revised November 2005, March 2011, July 2014, and August 2018. Visit the EDIS website at https://edis.ifas.ufl.edu for the currently supported version of this publication.

2. D. C. Odero, associate professor, Agronomy Department, UF/IFAS Everglades Research and Education Center; and M. VanWeelden, agronomic crops Extension agent, UF/IFAS Extension Palm Beach County; UF/IFAS Extension Gainesville, FL 32611.

The use of trade names in this publication is solely for the purpose of providing specific information. UF/IFAS does not guarantee or warranty the products named, and references to them in this publication do not signify our approval to the exclusion of other products of suitable composition.

Use herbicides safely. Read and follow directions on the manufacturer's label.

The Institute of Food and Agricultural Sciences (IFAS) is an Equal Opportunity Institution authorized to provide research, educational information and other services only to individuals and institutions that function with non-discrimination with respect to race, creed, color, religion, age, disability, sex, sexual orientation, marital status, national origin, political opinions or affiliations. For more information on obtaining other UF/IFAS Extension publications, contact your county's UF/IFAS Extension office. 


\section{Field Sanitation and Tillage}

The first step in an effective weed management program is to ensure a solid, uniform stand of rice. Plant only high quality, uncontaminated, certified rice seed. The Florida state regulations for rice seed certification specify that a maximum of $0.05 \%$ weed seed is allowed in certified rice seed. There is zero tolerance for "objectionable" or "noxious" weed seeds, as listed in the General Seed Certification Standards. These include red rice (Oryza sativa), purple nutsedge, and Texas panicum (P. texanum).

Plant rice in a well-prepared seedbed that receives a final cultivation as close to planting as possible (Figure 1). Cultivation immediately before planting destroys existing weeds and allows the rice to compete with later emerging weeds. On lighter muck soils, rolling the field before drill seeding allows for more precise planting depth and greater uniformity of emergence. Planting in a dry seedbed may require that the field be "flushed" immediately after planting to help ensure uniform rice germination and emergence. The duration of a flush will vary depending on the size of the field, the soil type, and how level the field is. The goal is to get the water on and off the planted field in approximately 48 hours. A poor stand of rice encourages infestation by weeds, which can become established in areas of open water where the rice population is sparse. In a solid stand of rice, weeds are usually not as competitive for essential sunlight and do not become very problematic.

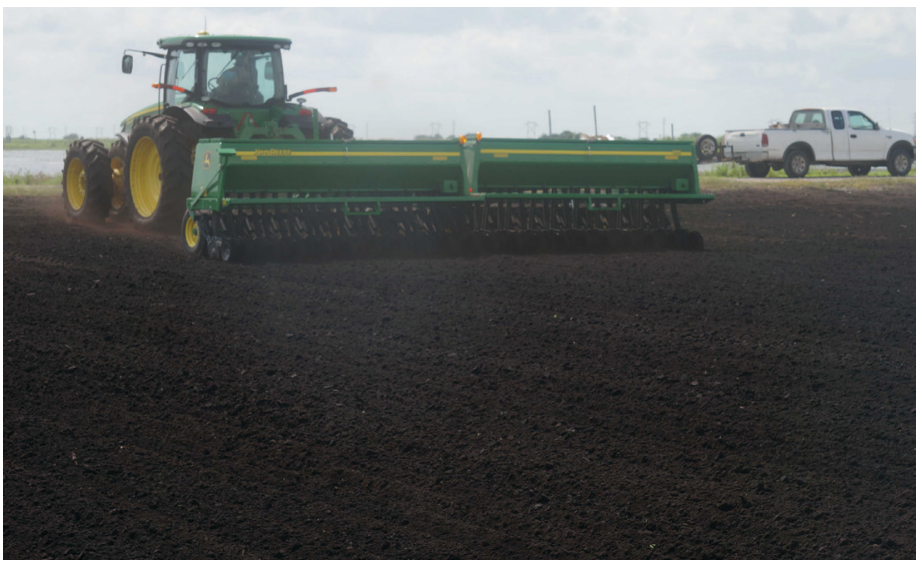

Figure 1. Rice planting in the Everglades Agricultural Area. Credits: Calvin Odero, UF/IFAS

\section{Water Management}

Apply the permanent flood as soon as possible in order to suppress weed seed germination. Weed seeds require oxygen to germinate, and flooding limits oxygen available for germination (Figure 2). The timing of the flood will depend on the growth rate of the rice crop, which is largely controlled by the planting date. The degree to which the field is level also plays an important role in flood timing.
Take care not to flood over and drown the rice in the lower area of the field. Typically, a permanent flood is applied 3-6 weeks after planting.

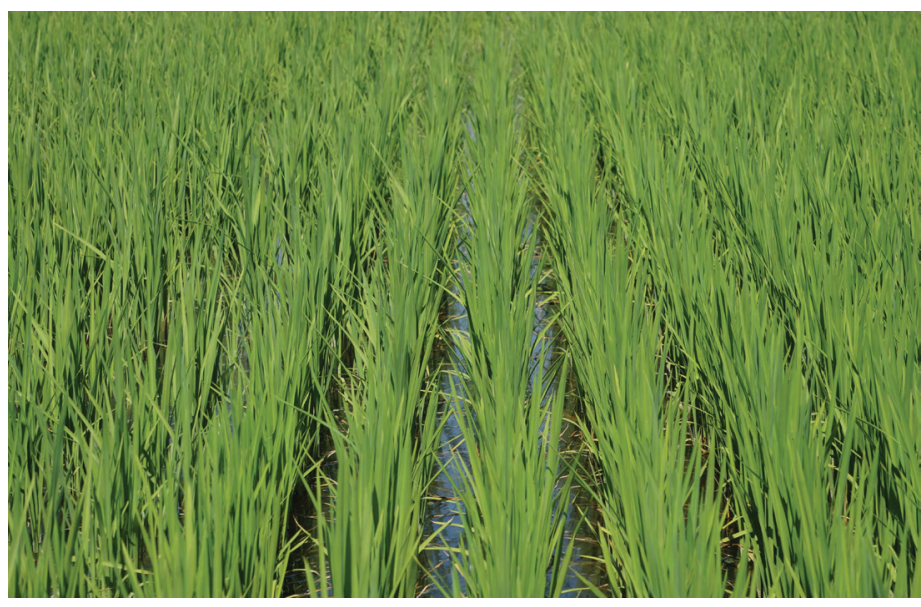

Figure 2. Flooded rice in the Everglades Agricultural Area. Credits: Calvin Odero, UF/IFAS

The most concentrated weed-control effort should be targeted for the time span between rice emergence and the application of the permanent flood. Two sets of tools can be used in an effective weed control program in rice: water management and chemical control. Chemical control (Table 1) will be effective only if the herbicides are used in conjunction with a carefully controlled water management plan.

Water management for weed control is effective in Florida because most of the weed species in our rice crops are only semi-aquatic weeds, and their growth can be impeded and ultimately controlled by standing water. In order to control rice weeds solely by water management, the grower is walking a fine line between killing the weeds and killing the rice. A high level of management skill and intensity is required. The theory behind water management for weed control is that rice can tolerate submergence better than many weed species. Therefore, the grower must know what weed species are potential problems and whether or not these weeds are easily controlled by submergence. Drillseeded rice can also be killed by submergence if permanent flooding is initiated too soon.

Anoxic or drowned rice will appear pale and flaccid and will not stand up after the flood has been taken off. The water depth should be kept as shallow as possible while still keeping all of the weeds totally submerged. The maximum allowable submergence time for rice depends on the water temperature because of the direct effect of temperature on plant respiration rate. The higher the water temperature, the shorter the maximum survivable duration of submergence. Typically, on most light- to medium-textured muck soils, rice can tolerate submergence for approximately 48 hours. 
On heavier mucks and high-mineral muck soils, rice will only tolerate shorter periods of flooding. After draining, the rice is allowed to recover for a week to 10 days, and then the flood cycle is repeated once or twice before the permanent flood is applied.

\section{Herbicides}

In the EAA, only a few commercial herbicides are widely used for postemergence chemical weed control in rice (Table 1). Preemergence herbicides are not commonly used in the Florida rice production system. Other herbicides are labeled for use in Florida rice production, but their use patterns are generally not appropriate to the Florida production system except under special conditions. As with any agricultural chemical, consult the product label and make sure you understand the recommendations before you use the product.

The underlying strategy behind using herbicides for weed control in rice is to kill or stunt the growth of weedy plants while allowing the rice plants to grow and achieve a competitive height advantage. Maintaining an effective height differential between the rice and weeds will allow the flood water to control weed growth by keeping them submerged while the rice plants grow above the water surface after the permanent flood is applied. If you can achieve a good height differential between the weeds and the rice near the time of permanent flood, you might not need herbicide, particularly at very low weed thresholds. Herbicide users must read the label and follow all instructions and precautions carefully.

\section{Stam M4, 80, and Others}

Of the herbicides available for weed control in Florida rice, Stam M4 (4 pounds active ingredient per gallon formulation of propanil) has been the most commonly used. Early applications of 2 to 3 pints per acre to small weeds and rice in the 1- to 2-leaf stage are most effective. At this timing, the herbicide is less phytotoxic to the rice seedlings, and the smaller weeds are more sensitive. Stam should be applied in no less than 10 gallons of water carrier per acre to obtain good spray coverage of weed foliage.

Because Stam is a contact herbicide and supplies no residual control, a second application of 1 to 1.5 pints per acre before permanent flood may be necessary. Second applications should be made to rice in the 5- to 6-leaf growth stage and followed by the permanent flood within 24 to 48 hours. Avoid applications at the 3 - to 4-leaf stage because during this growth stage, rice plants are extremely sensitive to the herbicide and are less able to recover from phytotoxic stress.
If weed pressure is light, a single early-season application of Stam may be all that is necessary in order to ensure an adequate height differential between the rice and the weeds so that the permanent flood will effectively control weed growth. If you missed the opportunity to spray early, a single late-season "salvage" application can be helpful. Since late-season Stam applications must be at the lower rate, it is essential that the permanent flood be established within 24 to 48 hours after herbicide application in order to achieve satisfactory control of large weeds. Stam activity increases at daily maximum temperatures above $75^{\circ} \mathrm{F}$ and decreases as temperatures decline below $75^{\circ} \mathrm{F}$. Poor weed control will occur at low temperatures (below $65^{\circ} \mathrm{F}$ ) and rice injury can occur at very high temperatures. Do not apply more than 6 pounds active ingredient per acre of Stam in a single season.

\section{Clincher}

Many rice growers in Florida use Clincher (2.38 pounds active ingredient per gallon formulation of cyhalofop) instead of Stam for grass control because of phytotoxicity associated with Stam particularly at high temperatures. Clincher controls a wide spectrum of annual grasses, such as barnyardgrass, fall panicum, and junglerice and can be applied from 1-leaf rice to 60 days before harvest with no phytotoxic effect on rice (Figure 3). This herbicide can be tank mixed with sedge herbicides to broaden the weed control spectrum in rice; however, tank mixes with broadleaf weed herbicides can result in reduced grass control. Reduced grass control may also occur if herbicide is applied under dry conditions or on grass species at advanced stages of growth. Use a buffering agent if the spray solution $\mathrm{pH}$ is $>8$ to lower the $\mathrm{pH}$ to $<8$. Apply Clincher in no less than 10 gallons of water carrier per acre to obtain good spray coverage. In flooded fields, it is recommended that grass weeds be at least $70 \%$ exposed for good efficacy. If fields are drained at application, they should be reflooded within 24 to 48 hours to prevent germination of new weeds. The use rates range from 13.5 to 15 fluid ounces per acre. The maximum single application rate of Clincher is 15 fluid ounces and not more than 25 fluid ounces should be applied per year in both the first and ratoon crops. Addition of crop oil concentrate or methylated seed oil at a minimum of 1 quart per acre must be used for all applications of Clincher.

\section{Sandea (Permit and Others)}

Sandea (75\% active ingredient of halosulfuron-methyl by weight) provides good control of yellow and purple nutsedge. The nutsedge species are among the most common weeds found in Florida rice. Sandea can be applied from planting until field flooding, and can be tank-mixed with 
Clincher or Stam for control of grassy weeds. Some propanil formulation labels indicate that any tank mixture is done at the user's risk due to the possibility of reduced control or increased injury; consult the propanil label for specific information before tank mixing with Sandea. Sandea can be mixed with Clincher, Aim, Basagran, Londax, or Grasp for additional broadleaf weed control. The use rates range from 0.67 to 1.33 ounces per acre, with total application not to exceed 1.33 ounces of product per acre per 12-month period. Sandea should not be applied within 48 days of harvest. For best results, add 0.25 to $0.5 \%$ v/v nonionic surfactant or $1.0 \% \mathrm{v} / \mathrm{v}$ crop oil concentrate.



Figure 3. Rice field. Left side treated with Clincher for fall panicum control; right side untreated.

Credits: Calvin Odero, UF/IFAS

\section{Londax}

Londax (60\% active ingredient of bensulfuron-methyl by weight) is primarily used for yellow nutsedge control in rice. It can be applied preflood and postflood as a tank mix with propanil-containing herbicides for control of sedges and broadleaf weeds. Permanent flood should be initiated within 7 days of application for best weed control results. Failure to maintain permanent flooding following application may result in poor performance due to regrowth of treated plants or re-infestation of newly germinated seedlings. The use rate ranges from 1.0 to 1.67 ounces per acre with a maximum of 1.67 ounces in a single growing season. Londax ( 0.75 to 1.0 ounce per acre) can also be tank mixed with Sandea ( 0.125 to 0.25 ounce per acre) for improved control of broadleaf weeds and sedges. For best results, add $0.25 \% \mathrm{v} / \mathrm{v}$ nonionic surfactant or $1.0 \% \mathrm{v} / \mathrm{v}$ crop oil concentrate. Londax has a 60-day preharvest interval and should be applied in no less than 10 gallons of water carrier per acre to obtain good spray coverage.

\section{Aim}

Aim (2 pounds active ingredient per gallon formulation of carfentrazone-ethyl) is a contact herbicide primarily used for broadleaf weed control in rice. It can be tank mixed with other rice herbicides such as Stam to broaden the weed control spectrum. For postemergence preflood applications, apply Aim at 1.25 to 3.2 fluid ounces per acre to weeds up to 4 inches tall for optimum results. For best results, add $0.25 \% \mathrm{v} / \mathrm{v}$ nonionic surfactant. Apply Aim before flooding, when rice is at the 2-leaf stage. Some phytotoxicity (speckling) may occur on rice after application of Aim. Flooding must be maintained for at least 23 days following treatment with Aim. Aim can also be used as a harvest aid (1.25 to 1.47 fluid ounces per acre) no earlier than soft dough (i.e. when starch in the grain is beginning to become firm but is still soft) up to 3 days before harvest.

\section{Basagran}

Basagran (4 pounds active ingredient per gallon formulation of bentazon) is a contact herbicide used for control of certain broadleaf weeds and sedges in rice. It is applied at 1.5 to 2.0 pints per acre when broadleaf weeds are small. Not more than 4 pints per acre per season of Basagran should be applied whether on a single crop or two. Basagran can be tank mixed with Londax or Stam to broaden the weed control spectrum, but do not use a crop oil concentrate with the Stam tank mix because it could injure the rice.

\section{Sharpen}

Sharpen ( 2.85 pounds active ingredient per gallon formulation of saflufenacil) is a contact herbicide for broadleaf weed control in rice. It can be used at 1.0 fluid ounce per acre with crop oil concentrate at $1 \% \mathrm{v} / \mathrm{v}$ when rice is at the 2-leaf stage up to stem elongation. Tank mix of Sharpen with Clincher may reduce the level of grass control. Take care when using Sharpen because it can cause injury on sensitive rice varieties.

Other herbicides available for use in rice but not currently used by many EAA growers include Grasp (penoxsulam), Grasp Xtra (premix of penoxsulam and triclopyr), and RebelEX (premix of cyhalofop and penoxsulam). Grasp is a low-use-rate herbicide for control of barnyardgrass and many broadleaf and annual sedges. Grasp Xtra and RebelEX deliver broad-spectrum control, targeting grasses and broadleaf and annual sedges. Consult the labels for these herbicides to ensure there is no rotational restriction on the crop that would follow rice. 
Table 1. Weed management in rice.

\begin{tabular}{|c|c|c|}
\hline $\begin{array}{l}\text { Trade Name and } \\
\text { Broadcast Rate/ } \\
\text { Acre of Commercial } \\
\text { Product }\end{array}$ & $\begin{array}{l}\text { Common Name and } \\
\text { Broadcast Rate/Acre of } \\
\text { Active Ingredient }\end{array}$ & Remarks \\
\hline $\begin{array}{l}\text { Aim EC } \\
(1.6-3.2 \text { fl. oz) }\end{array}$ & $\begin{array}{l}\text { carfentrazone-ethyl } \\
(0.025-0.05 \mathrm{lb})\end{array}$ & $\begin{array}{l}\text { Preflood/Postemergence: Best control is obtained when applied to weeds less than } 4 \text { inches } \\
\text { tall. Apply when rice is at the } 2 \text {-leaf stage or larger, but before flooding. Use a nonionic } \\
\text { surfactant at } 0.25 \% \mathrm{v} / \mathrm{v} \text { or crop oil concentrate at } 0.5 \% \text { to } 1.0 \% \mathrm{v} / \mathrm{v} \text { for greater activity. } \\
\text { Some temporary leaf spotting (speckling) may occur after treatment. Excellent control of } \\
\text { pigweeds and suppression of redstem, alligatorweed, and Texasweed. }\end{array}$ \\
\hline $\begin{array}{l}\text { Aim EC } \\
(1.6-6.3 \text { fl. oz) }\end{array}$ & $\begin{array}{l}\text { carfentrazone-ethyl } \\
(0.025-0.1 \mathrm{lb})\end{array}$ & $\begin{array}{l}\text { Postflood/Postemergence to Exposed Weeds: Apply to rice and weeds after permanent flood } \\
\text { and when } 80 \% \text { of the foliage of the weeds is exposed. Use } 0.25 \% \mathrm{v} / \mathrm{v} \text { nonionic surfactant } \\
\text { or } 0.5 \% \text { to } 1.0 \% \mathrm{v} / \mathrm{v} \text { crop oil concentrate. Apply when rice is at } 2 \text {-leaf stage or later before } \\
\text { internode elongation. }\end{array}$ \\
\hline $\begin{array}{l}\text { Bolero } 8 \mathrm{EC} \\
(4.0 \mathrm{pt})\end{array}$ & $\begin{array}{l}\text { thiobencarb } \\
(4.0 \mathrm{lb})\end{array}$ & $\begin{array}{l}\text { Preemergence control of grasses and broadleaf weeds. Soil must be moist at application. } \\
\text { Apply as soon as possible after planting and following a post-planting flushing if soil is } \\
\text { dry. }\end{array}$ \\
\hline $\begin{array}{l}\text { Stam M4 } \\
(3.0-4.0 \text { qt) } \\
\text { (early application) } \\
\text { or } \\
\text { Stam } 80 \text { EDF } \\
(3.75-5.0 \mathrm{lb})\end{array}$ & $\begin{array}{l}\text { propanil } \\
(3.0-4.0 \mathrm{lb})\end{array}$ & $\begin{array}{l}\text { Early application occurs at the 1- to 4-leaf stage of rice. Contact herbicide activity on } \\
\text { grasses and broadleaf weeds. Poor weed control may occur at cool temperatures (best } \\
\text { activity at temperatures above } 75^{\circ} \text { F) and rice injury will occur at high temperatures (above } \\
95^{\circ} \text { F). Spray adjuvants are required for the dry formulation and not for the emulsifiable } \\
\text { concentrate (EC) formulation. Maximum application of } 6 \mathrm{lb} \text { a.i. per acre in a single growing } \\
\text { season. }\end{array}$ \\
\hline $\begin{array}{l}\text { Stam M4 } \\
\text { (4-6 qt) } \\
\text { (late application) } \\
\text { or } \\
\text { Stam } 80 \text { EDF } \\
(5-7.5 \mathrm{lb})\end{array}$ & $\begin{array}{l}\text { propanil } \\
(4-6 \mathrm{lb})\end{array}$ & $\begin{array}{l}\text { Application at the 3- to 4-leaf stage is not recommended because of phytotoxicity. } \\
\text { Late application is at the 5- to 6-leaf stage of rice in combination with the application } \\
\text { of permanent flood. A higher rate ( } 5 \text { to } 6 \mathrm{qt} / \text { acre) can be used as a salvage (rescue) } \\
\text { operation for emergency control of tillering grasses. See above comments on application } \\
\text { requirements. }\end{array}$ \\
\hline $\begin{array}{l}\text { Stam M4 } \\
\text { (3.0-4.0 pt) } \\
\text { or } \\
\text { Stam } 80 \mathrm{EDF} \\
(3.75-5.0 \mathrm{lb}) \\
+ \\
\text { Bolero } 8 \mathrm{EC} \\
(3.0-4.0 \mathrm{pt})\end{array}$ & $\begin{array}{l}\text { propanil } \\
(3.0-4.0 \mathrm{lb}) \\
+ \\
\text { thiobencarb } \\
(3.0-4.0 \mathrm{lb})\end{array}$ & $\begin{array}{l}\text { See previous remarks for compounds used individually. Apply at the 1- to 2-leaf stage of } \\
\text { rice. Soil must be moist at application. }\end{array}$ \\
\hline $\begin{array}{l}\text { Basagran } \\
(1.5-2.0 \mathrm{pt})\end{array}$ & $\begin{array}{l}\text { bentazon } \\
(0.75-1.0 \mathrm{lb})\end{array}$ & $\begin{array}{l}\text { Best control is achieved with early application. Yellow nutsedge ( } 4 \text { to } 6 \text { leaf) may be } \\
\text { controlled with the lower rate. Also, it can provide some control of dayflower and redstem. } \\
\text { Higher rates needed for larger yellow nutsedge. Do not apply more than } 2 \mathrm{lb} \text { a.i. per acre } \\
\text { in a single season. May be tank mixed with Stam M4 for mixed weed populations. Add a } \\
\text { crop oil concentrate at } 1.25 \% \mathrm{v} / \mathrm{v} \text { for the tank mix. Continuous agitation is necessary. }\end{array}$ \\
\hline $\begin{array}{l}\text { Londax } \\
(1-1.66 \mathrm{oz})\end{array}$ & $\begin{array}{l}\text { bensulfuron-methyl } \\
(0.0375-0.0626 \mathrm{lb})\end{array}$ & $\begin{array}{l}\text { Best control is obtained when applied early postemergence to small, actively growing } \\
\text { weeds. Can be applied to flooded rice; see label for specific requirements. Controls } \\
\text { Mexicanweed, Texasweed, and yellow nutsedge. Can suppress growth of alligatorweed. } \\
\text { Does not offer control of most grass weeds but can be tank mixed with Stam to enhance } \\
\text { the weed control spectrum. Add an } 80 \% \text { nonionic surfactant }(0.25 \% \mathrm{v} / \mathrm{v}) \text { or crop oil } \\
\text { concentrate }(1.0 \% \mathrm{v} / \mathrm{v}) \text { when applied alone or with a dry formulation of Stam. }\end{array}$ \\
\hline $\begin{array}{l}\text { Regiment } \\
(0.4-0.57 \mathrm{oz})\end{array}$ & $\begin{array}{l}\text { bispyribac-sodium } \\
(0.02-0.0285 \mathrm{lb})\end{array}$ & $\begin{array}{l}\text { Most effective when applied early postemergence to small, actively growing weeds, } \\
\text { but after rice is at the 3-leaf stage. Can be applied before or after establishment of a } \\
\text { flood. Provides excellent control of barnyardgrass. Can suppress growth of Texasweed, } \\
\text { Mexicanweed, and alligatorweed. }\end{array}$ \\
\hline $\begin{array}{l}\text { Prowl } \mathrm{H}_{2} \mathrm{O} \\
(1.5-2.0 \mathrm{pt})\end{array}$ & $\begin{array}{l}\text { pendimethalin } \\
(0.71-0.95 \mathrm{lb})\end{array}$ & $\begin{array}{l}\text { For delayed preemergence grass control. The soil should be sealed by rain or flushed } \\
\text { and drained before application to ensure that rice seeds have imbibed water. Apply } \\
\text { after rice planting and before rice spiking and weed germination. Exposed rice may be } \\
\text { severely injured. May be used as a tank mix with propanil as very early postemergence } \\
\text { application in drill-seeded rice. DO NOT USE ON MUCK SOILS. DO NOT USE ON SANDS } \\
\text { FOR DELAYED PREEMERGENCE. Controls fall panicum, barnyardgrass, junglerice, and } \\
\text { sprangletop. }\end{array}$ \\
\hline
\end{tabular}




\begin{tabular}{|c|c|c|}
\hline $\begin{array}{l}\text { Trade Name and } \\
\text { Broadcast Rate/ } \\
\text { Acre of Commercial } \\
\text { Product }\end{array}$ & $\begin{array}{l}\text { Common Name and } \\
\text { Broadcast Rate/Acre of } \\
\text { Active Ingredient }\end{array}$ & Remarks \\
\hline $\begin{array}{l}\text { Command } 3 \mathrm{ME} \\
\text { (11-34 fl oz) }\end{array}$ & $\begin{array}{l}\text { Clomazone } \\
(0.25-0.8 \mathrm{lb})\end{array}$ & $\begin{array}{l}\text { For preemergence control of barnyardgrass, sprangletop, and fall panicum. Apply from } \\
14 \text { days before seeding to } 7 \text { days after seeding but before weed emergence. Higher rates } \\
\text { should be used on muck soils. }\end{array}$ \\
\hline $\begin{array}{l}\text { Sharpen } \\
\text { (1 fl oz) }\end{array}$ & $\begin{array}{l}\text { Saflufenacil } \\
(0.0223 \mathrm{lb})\end{array}$ & $\begin{array}{l}\text { For broadleaf weed control from 2-leaf rice up to internode elongation. Apply with } 1.0 \% \\
\text { v/v crop oil concentrate. Transient rice leaf burn may occur but will not persist for more } \\
\text { than } 14 \text { days. }\end{array}$ \\
\hline $\begin{array}{l}\text { Ultra Blazer } \\
(0.5 \mathrm{pt})\end{array}$ & $\begin{array}{l}\text { acifluorfen } \\
(0.125 \mathrm{lb})\end{array}$ & $\begin{array}{l}\text { For use as a postemergence application for hemp sesbania control. Apply from late } \\
\text { tillering up to early boot stage of rice. Do not apply after boot stage. Use an } 80 \% \text { nonionic } \\
\text { surfactant at } 0.125 \% \text { to } 0.25 \% \text { v/v in spray mix. Can be tank mixed with Stam. }\end{array}$ \\
\hline $\begin{array}{l}\text { Sandea } \\
(0.67-1.33 \mathrm{oz})\end{array}$ & $\begin{array}{l}\text { halosulfuron-methyl } \\
(0.032-0.0623 \mathrm{lb})\end{array}$ & $\begin{array}{l}\text { Provides control of purple and yellow nutsedges. Also provides some control of redroot } \\
\text { pigweed, common ragweed, and several other broadleaf species; see product label } \\
\text { for details. Use } 0.67 \text { oz/acre for nutsedges less than } 6 \text { inches tall and } 1 \text { to } 1.33 \mathrm{oz} / \\
\text { acre for nutsedges } 6 \text { to } 12 \text { inches tall. When applied alone, Sandea may be used for } \\
\text { postemergence weed control from before the emergence of rice until field flooding } \\
\text { occurs. Do not apply within } 28 \text { days of harvest. Add an } 80 \% \text { active nonionic surfactant } \\
\text { at } 0.25 \% \text { to } 0.5 \% \text { v/v or a crop oil concentrate containing at least } 14 \% \text { emulsifiers at a } \\
\text { rate of } 1.0 \% \mathrm{v} / \mathrm{v} \text {. It can be tank mixed with Stam M } 4 \text { or Clincher to broaden weed control } \\
\text { spectrum. The adjuvants should not be added when tank mixed with the EC formulation } \\
\text { of propanil. }\end{array}$ \\
\hline $\begin{array}{l}\text { Clincher } \\
\text { (13.5-15 fl oz/ac) }\end{array}$ & $\begin{array}{l}\text { cyhalofop-butyl } \\
(0.25-0.28 \mathrm{lb})\end{array}$ & $\begin{array}{l}\text { Provides grass control (fall panicum, sprangletop) from 1-leaf rice to } 60 \text { days before } \\
\text { harvest. Add a crop oil concentrate or methylated seed oil at } 1.0 \text { qt/acre. Tank mix with } \\
\text { broadleaf or sedge herbicides may result in reduced grass control. Do not apply more } \\
\text { than } 25 \mathrm{oz} / \text { acre in a single season. }\end{array}$ \\
\hline $\begin{array}{l}\text { Grasp SC } \\
(2-2.3 \text { fl oz/ac) }\end{array}$ & $\begin{array}{l}\text { penoxsulam } \\
(0.036-0.44 \mathrm{lb})\end{array}$ & $\begin{array}{l}\text { Provides control of grasses, broadleaf, and annual sedges. Apply from early } \\
\text { postemergence (1-leaf rice) to } 60 \text { days before harvest. Add a crop oil concentrate or } \\
\text { methylated seed oil at } 1 \text { qt/acre. Flooding should be delayed for } 3 \text { days following } \\
\text { application. }\end{array}$ \\
\hline $\begin{array}{l}\text { Grasp Xtra } \\
\text { (16-22 fl oz/ac) }\end{array}$ & $\begin{array}{l}\text { penoxsulam }+ \text { triclopyr } \\
(0.031-0.043 \mathrm{lb}+ \\
0.19-0.26 \mathrm{lb})\end{array}$ & $\begin{array}{l}\text { Provides control of grasses, broadleaf, and annual sedges. Apply to } 2 \text { - to } 3 \text {-leaf stage } \\
\text { rice or after } 1 / 2 \text {-inch internode elongation stage of rice. Add a crop oil concentrate } \\
\text { or methylated seed oil at } 1 \mathrm{qt} / \text { acre. Flooding should be delayed for } 3 \text { days following } \\
\text { application. }\end{array}$ \\
\hline
\end{tabular}

